\title{
3，腎不全患者の心血管イベントの ターゲットとしての酸化ストレス
}

一第 50 回日本透析医学会・第 48 回日本腎臓学会合同ワークショップよりー

\author{
下澤 達 雄 \\ 東京大学医学部附属病院検査部
}

腎不全患者には効率に心血管イベントが生じること が知られている，腎不全と心血管イベントにはいくつ かの共通するリスクファクターがある. 中でも，血圧， インスリン抵抗性, 脂質代謝異常あるいは加齢といつ たリスクは従来より知られており,これらのリスク ファクターは相互に密接に関連するものである. 現在, 糖コントロール，あるいはレニンアンジオテンシン系 や炎症に注目され積極的な介入が行われている。しか し，現在のところ十分な効果をあげているとはいえな い. 最近, 酸化ストレスもまた, 共通するリスクファ クターとして注目されてきた（図）。

実際，われわれは腹膜透析患者において全身の酸化 ストレスマーカーである $8 \mathrm{OHdG}$, ペントシジン, MDA-LDL が正常人にくらべ増加しており，また，血 管障害のマーカーである脈波速度と相関があることを 見出している.このことから，われわれは酸化ストレ スが透析患者における心血管イベント発症に深く関与 する可能性を考え，基礎的検討を行い，また，治療へ の応用となる検討を行った.

酸化 LDL 受容体 LOX-1 は慢性腎不全モデルラッ トや，ダール食塩感受性ラットにおいて腎障害に伴い その発現が増加する (Nagase M. et al. J Am Soc Nephrol 2000；11: 1826-1836, J Biol Chem. 273 : 33702-33707, 1998) ことが示されている. さらに，こ の LOX-1 は酸化ストレスによりその発現が亢進する ことがわかっている。これらのことから, LOX-1 が新 たな腎障害のマーカーであるとともに，酸化ストレス や酸化 LDL が腎障害発症にかかわる可能性が考えら れる。

一方，アドレノメデュリンは血管拡張物質であるだ けでなく，抗酸化物質であることが最近わかった。す なわち，われわれが作成したアドレノメデュリンノッ クアウトマウスの検討では, 酸化ストレスの増加とと

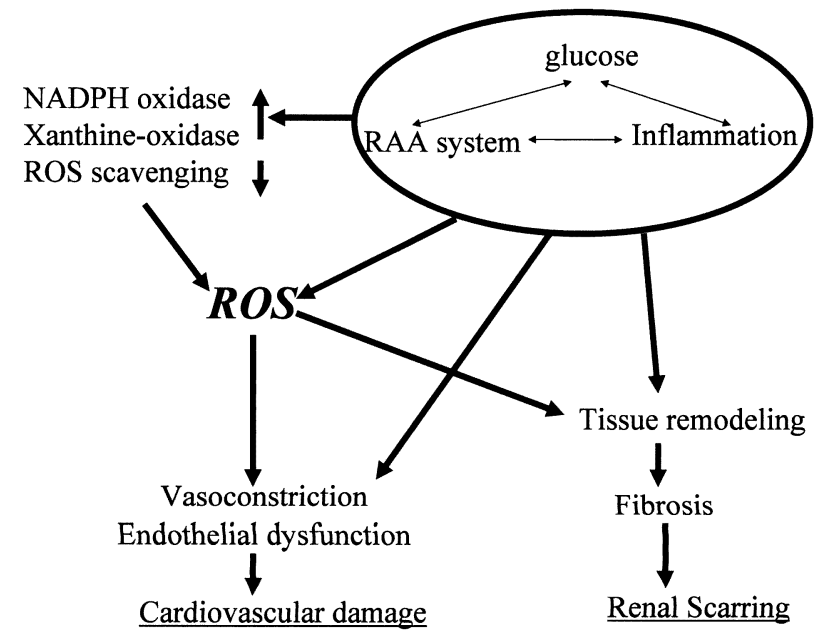

図 酸化ストレスと臓器障害

もに, 冠動脈病変, 血管障害が発症し, 抗酸化剤ある いはアドレノメデュリンの補充により血管病変の治療 が可能であることを報告した（Shimosawa T. et al. Circulation $2002 ; 105: 106-111$, Kawai J. et al. Circulation $2004 ; 109: 1147-1153$, Matsui H. et al. Circulation 109 :2246-2251). すなわちアンジオテン シンII負荷, 低酸素, 動脈周囲のカフ留置による機械 的刺激, 加齢モデルのいずれにおいても, 酸化ストレ スの増大により血管障害が生じた。われわれは酸化ス トレスを尿中のイソプロスタン排泄，80HdG 排泄に より全身の状態を評価し, 局所は 3-nitrotyrosine 染色 で評価した.リアルタイムでの酸化ストレスの産生は 電子スピン共鳴法あるいはルシジェニンを用いた蛍光 測定法により検討している。 また，最近の検討では UUO モデルにおいて，酸化ストレスの京進にともな い,アドレノメデュリン欠損マウスでは腎障害が重篤 となり, LOX-1の発現も克進することがわかった。一 方, このマウスに抗酸化薬あるいはアドレノメデュリ ンを投与することにより, LOX-1 の発現を抑制し, 腎

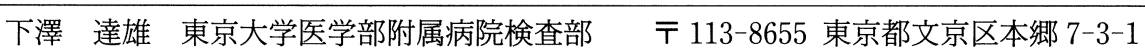

Tatsuo Shimosawa Tel : 03-3815-5411 Fax : 03-5689-0495 
障害を軽減することができた。

さらに末期腎不全には糖尿病性腎症が増加している こと，あるいは腹膜透析では高糖の透析を用いること から, 血糖値と酸化ストレス, 細胞障害について特に 腹膜中皮細胞を用いて検討した．糖負荷により中皮細 胞はフィブロネクチン, $\mathrm{TGF} \beta$ の発現を 24 時間後か ら増加させる.一方, 酸化ストレスはそれよりも早く, 30 分後から上昇する.この酸化ストレスはルシジェニ ンアッセイにより NADPH oxidase 由来であること が明らかとなった。ささら実際臨床上ではレニンアン ジオテンシン系の抑制が糖によるさまざまな蔵器障害 の予防に有効なことから，アンジオテンシン II 拮抗薬
の効果を検討したところ, 24 時間後のフィブロネクチ ン, TGF $\beta$ の発現は程度の差がみられたがアンジオテ ンシンII拮抗薬により抑制された。一方，酸化ストレ スも糖負荷後 8 時間後ではいずれのアンジオテンシン II拮抗薬でも抑制されたが，オルメサルタンのみ糖付 加後 30 分の酸化ストレスの抑制効果が認められ, この 作用はアンジオテンシンIIを介するものではなく, 直 接にNADPH oxidase の活性を抑制している可能性 が考えられた。

以上の基礎的検討と臨床検討から，抗酸化を目的と した治療は腎不全患者における心血管障害を効果的に 治療，予防できる可能性を示すと考えられる. 